\title{
Correction to: Exploring socioeconomic inequities in access to palliative and end-of-life care in the UK: a narrative synthesis
}

Maddy French ${ }^{1 *}$, Thomas Keegan², Eleftherios Anestis ${ }^{1}$ and Nancy Preston ${ }^{1}$

Correction to: BMC Palliative Care 20, 179 (2021)

https://doi.org/10.1186/s12904-021-00878-0

Following the publication of the original article [1], the author reported that a phrase in the abstract section was omitted during production process.

The sentence currently reads:

Efforts inequities in access to palliative and end-of-life care require comprehensive understanding about the extent of and reasons for inequities.

The sentence should read:

Efforts to tackle socioeconomic inequities in access to palliative and end-of-life care require comprehensive understanding about the extent of and reasons for inequities.

The original article has been updated.

Author details

${ }^{1}$ Division of Health Research, Lancaster University, Lancaster, UK. ${ }^{2}$ Lancaster

Medical School, Lancaster University, Lancaster, UK.

Published online: 12 December 2021

\section{Reference}

1. French M, Keegan T, Anestis E, et al. Exploring socioeconomic inequities in access to palliative and end-of-life care in the UK: a narrative synthesis. BMC Palliat Care. 2021;20:179. https://doi.org/10.1186/ s12904-021-00878-0.

The original article can be found online at https://doi.org/10.1186/s12904021-00878-0.

*Correspondence: m.french4@lancaster.ac.uk

${ }^{1}$ Division of Health Research, Lancaster University, Lancaster, UK

Full list of author information is available at the end of the article

(C) The Author(s) 2021. Open Access This article is licensed under a Creative Commons Attribution 4.0 International License, which permits use, sharing, adaptation, distribution and reproduction in any medium or format, as long as you give appropriate credit to the original author(s) and the source, provide a link to the Creative Commons licence, and indicate if changes were made. The images or other third party material in this article are included in the article's Creative Commons licence, unless indicated otherwise in a credit line to the material. If material is not included in the article's Creative Commons licence and your intended use is not permitted by statutory regulation or exceeds the permitted use, you will need to obtain permission directly from the copyright holder. To view a copy of this licence, visit http://creativecommons.org/licenses/by/4.0/. The Creative Commons Public Domain Dedication waiver (http://creativeco mmons.org/publicdomain/zero/1.0/) applies to the data made available in this article, unless otherwise stated in a credit line to the data. 